University of Nebraska - Lincoln

DigitalCommons@University of Nebraska - Lincoln

June 1988

\title{
Contemporary Philosophy of Science and Neoinstitutional Thought
}

Ann Mari May

University of Nebraska - Lincoln, amay1@UNL.edu

Follow this and additional works at: https://digitalcommons.unl.edu/cbafacpub

Part of the Business Commons

May, Ann Mari, "Contemporary Philosophy of Science and Neoinstitutional Thought" (1988). College of Business Faculty Publications. 20.

https://digitalcommons.unl.edu/cbafacpub/20

This Article is brought to you for free and open access by the Business, College of at DigitalCommons@University of Nebraska - Lincoln. It has been accepted for inclusion in College of Business Faculty Publications by an authorized administrator of DigitalCommons@University of Nebraska - Lincoln. 


\title{
Contemporary Philosophy of Science and Neoinstitutional Thought
}

\author{
Ann Mari May \\ and \\ John R. Sellers
}

Logicians cannot make sense of science-but they can make sense of logic and so they stipulate that science must be presented in terms of their favorite logical system. This would be excellent comedy material were it not the case that by now almost everyone has started taking the logician seriously.'

Orthodox neoclassical economists as well cannot make sense of economics, but they too can make sense of logic and so they stipulate that economics must be presented in terms of their favorite logical system - logical empiricism-and therein lies one of the fundamental stumbling blocks to progress within the discipline of economics. The neoclassical paradigm that now dominates the profession is purportedly based upon a methodological foundation of logical empiricism, which the neoclassical economists themselves cannot conform to, but which nonetheless has proven to be quite useful in undercutting the legitimacy of those alternative research programs that do not support the ideological conclusions of neoclassicism. One such alternative research pro-

The authors are, respectively, Assistant Professor of Economics, University of NebraskaLincoln. and graduate student, University of Tennessee, Knoxville. They would like to thank Greg Hayden for his helpful comments on an earlier draft. This article was presented at a joint session of the Association for Evolutionary Economics and the Association for Social Economics, Chicago, Illinois, 28 December 1987. 
gram, neoinstitutional economics, has been conveniently dismissed as illegitimate because it is not "scientific"; that is, it does not conform to the rigorous demands of logical empiricism.

Although neoclassical economics does not meet the requirements of its own methodological precepts, our purpose is not to dwell on the inadequacies of the neoclassical paradigm or to discuss the substance of neoinstitutional thought. Rather, our purpose is to clarify the methodological foundations of neoinstitutional thought and to argue that neoinstitutional economics represents a legitimate research program that is, by virtue of its methodology, more consistent with recent developments in the philosophy of science.

\section{The Positivist Tradition and Neoclassical Economics}

The philosophy of science in the twentieth century has encompassed the rise of logical positivism, its maturation in logical empiricism, and a fundamental attack thereon through the growth of knowledge tradition of Thomas Kuhn, Paul Feyerabend, and others. ${ }^{2}$ Logical empiricism grew in the 1940s and 1950s out of the tradition of logical positivism, which argued that science progresses through the application of logical analysis to empirical phenomena. In constructing scientific theories, only those statements that can be verified-that is, empirically observed-are accepted as meaningful statements in a theory. Logical empiricism evolved within this tradition in an effort to explicate the derivation of meaningful (verifiable) sentences for theory construction. When the prescription that every meaningful sentence of a theory be verifiable became too confining, the "emphasis shifted from the demarcation of scientific from nonscientific statements to the evaluation of competing theories." 3 The evaluation of theories rested upon a determination of the correspondence between theory claims and reality.

It is not difficult to demonstrate that neoclassicism does not conform to the methodological precepts of logical empiricism. Take, for example, the development of consumer theory in neoclassical theory. Consumer theory developed as a theory of choice whereby individuals maximize utility, subject to constraints. Because utility cannot be observed directly, Paul Samuelson set out to reconstruct consumer theory using only observational concepts. ${ }^{4}$ The resulting theory of revealed preference, as Stanley Wong has demonstrated, is based upon unrestricted universal sentences, contains non-observational terms, and, most importantly, derives conclusions that are non-observable. ${ }^{5}$

The problem facing neoclassicism is, however, more serious than the 
failure of Samuelson to derive an observational equivalent to ordinal utility theory. The fundamental problem for neoclassicism is that the maximization hypothesis, while untestable, remains at the core of the neoclassical research program and makes the hypotheses of neoclassicism nonrefutable. The logical positivist shift in emphasis away from the testability of individual sentences to evaluation of the empirical content of theories is meaningless when the theory is based upon something as unamenable to definition as the maximization hypothesis. One would have to agree with Mark Blaug that much of the empirical work in economics is like "playing tennis with the net down," and produces what Blaug has called "innocuous falsificationism."6

While one can quite easily argue that the religious-like devotion of neoclassical economists to positivism is anything but innocuous, this devotion is all the more striking when we consider that positivism has been in decline for more than twenty years within the philosophy of science. The attack on the positivist tradition accelerated in the 1960s with the criticism of Thomas Kuhn and Paul Feyerabend. The criticisms of post-positivists such as Kuhn and Feyerabend concurrently form the underlying foundation of the growth of knowledge tradition.

Three aspects of the growth of knowledge tradition are examined here: the emphasis on specificity over universality, the interactionist view, and the rejection of the normative-positive dichotomy. This tradition, it will be shown, has much in common with the epistemological foundations of neoinstitutional thought.

\section{Post-Positivism and the Critique of Logical Empiricism}

A fundamental aspect of the growth of knowledge tradition has been a recognition of the historical nature of inquiry and hence an emphasis on specificity over universality within the philosophy of science. According to Bruce Caldwell, "logical empiricists concerned themselves with the elaboration of universal models and procedural rules which they believed aptly characterized legitimate scientific practice." Feyerabend describes the process, the aim of positivists such as Karl Popper is to "develop a special point of view, to bring that point into logically acceptable form ... and then to discuss everything in its terms. ${ }^{8}$ In contrast, post-positivists such as Kuhn and Feyerabend are united in stressing the inseparability of the historical context of inquiry and the context of justification. "According to Kuhn science is a historical tradition ... it is not subjected to external rules, the rules that guide the scientist are not always known, and they change from one period to the next."9 Post-positivists are less concerned with developing 
a universal "scientific method" and more concerned with "the growth of knowledge over time, the dynamics of change within individual disciplines and the actual practices of scientists." 10 By stressing the historical aspect of inquiry, post-positivists minimize the prescriptive role of philosophy of science and, by acknowledging the heterogeneous process of inquiry, advocate methodological pluralism.

A second and related aspect of the post-positivist tradition concerns the "interactionist view" of science." The interactionist view of science concerns the relationship between the scientist qua investigator and the objective "fact" awaiting explanation. Instead of accepting as given the notion of an "objective" scientist merely evaluating empirical data, post-positivists emphasize the interaction of the scientist and the problem awaiting empirical examination. According to Feyerabend, science combines reason and practice. Logical analysis "serves as a guide who is part of the activity guided and is changed by it." 12 The interactionist view of science essentially views science as a problem-solving activity directed not by reason alone, but by the interaction of reason and practice.

Perhaps the most devastating aspect of the post-positivists' critique of logical empiricism has been their analysis of the normative-positive dichotomy. This distinction between normative and positive has been attacked by the post-positivists at several points within the philosophy of science.

First, facts do not exist independently of scientific theories; what is construed as a fact depends upon one's theoretical framework. "What confronts the observer is usually a choice of fact. Events have a way of outstripping observations and there is a richness to existence that compels a selection." 13 Thus the "subjective" perspective of the scientist influences the collection of the "objective" data. "On closer analysis we even find that science knows no 'bare facts' at all but that the 'facts' that enter our knowledge are already viewed in a certain way and are, therefore, essentially ideational."14

Furthermore, having chosen the "facts" to consider, observation of the facts also involves subjective perception. As Norwood Hanson points out: "In Kohler's famous drawing of the Goblet-and-faces we 'take' the same retinal/cortical/sense-datum picture of the configuration; our drawings might be indistinguishable. I see a goblet however, and you see two men staring at one another. Do we see the same thing? Of course we do. But then again we do not."15

For Kuhn, the subjective emphasis is not so much on perception as on interpretation, for "interpretation begins where perception ends. 
The two processes are not the same, and what perception leaves for interpretation to complete depends drastically on the nature and amount of prior experience and training." 16

It is clear from the above discussion that the normative-positive distinction represents a false dichotomy. Through selection, perception, and interpretation, "objective facts" reflect subjective judgments. The post-positivist distinction incorrectly divorces fact from value and subject from object. The criticisms of positivism embodied in the growth of knowledge tradition have been sufficiently effective to relegate the methodology of positivism and the positivist tradition to the archives of intellectual history. ${ }^{17}$ Moreover, the growth of knowledge tradition exposes the weaknesses of the Cartesian system that underlies positivism and its forced separation of fact and value, normative and positive. In recent decades, the philosophy of science has moved away from the Cartesian tradition toward an integration of fact and value. Similarly, neoinstitutionalists, through their methodological forbearers, the American pragmatists, have also sought to integrate fact and value.

\section{Post-Positivists Aspects of Neoinstitutional Thought}

Neoinstitutional thought combines the instrumental logic of John Dewey and the social value theory of Clarence Ayres, J. Fagg Foster, and Marc Tool. ${ }^{18}$ Although the epistemological foundation of neoinstitutional thought was developed by Dewey more than fifty years ago, it has much in common with the growth of knowledge tradition within the philosophy of science.

John Dewey viewed the process of inquiry as a distinctly historical process, not unlike Kuhn and Feyerabend. For Dewey, science was what scientists were doing as opposed to what philosophy said they were supposed to be doing. Furthermore, Dewey considered it incumbent on philosophy to adapt the method of inquiry to its own uses: "The central question thus arises: What determines the selection of operations to be performed? There is but one answer:- the nature of the problem to be dealt with." 19

As a historical process, instrumental logic emphasizes specificity over universality by taking as its focal point the problematic or unresolved situation. As Dewey points out, inquiry begins with a problematic situation-a real state of affairs, subject to question, testing, and possible resolution. The inquirer goes about the business of organizing facts and ideas according to their efficacy in resolving the problematic situation into a "unified whole." ${ }^{20}$ Dewey sees this as a creative process 
in which ideas "occur at first simply as suggestions. ... The suggestion becomes an idea when it is examined with reference to its functional fitness, its capacity as a means of resolving the given situation."21

The logic of inquiry recognizes no universal prescriptive method and emphasizes the interaction of the scientist and the environment through the process of experimentation. Through experimentation, theory and practice are linked together by necessity; one is meaningless without the other. This functional integration characterizes the experimental method as Dewey saw it. ${ }^{22}$

It is this integration of theory and practice through the experimental method that makes instrumentalism both a theory of logic and a principle of ethical analysis, and leads Dewey to eschew the normativepositive dichotomy. ${ }^{23}$ For Dewey, the process of valuation is unavoidable in inquiry because inquiry is directed by reference to a problem situation: "All conduct that is not simply either blindly impulsive or mechanically routine seems to involve valuations. The problem of valuation is thus closely associated with the problem of the structure of the sciences of human activities and human relations." ${ }^{24}$

Like Feyerabend, Dewey recognized that because science is a problemsolving activity, the selection of "facts" to be considered is determined by the subjective awareness of a problem situation. "To see that a situation requires inquiry is the initial step of inquiry." 25 However, whereas the growth of knowledge tradition recognizes the subjective nature of inquiry through selection, perception, and interpretation of "objective facts," the neoinstitutionalist tradition attempts to develop a theory of value to be used in evaluating and resolving the problem situation.

Social value theory is the cornerstone of the neoinstitutionalist perspective that is used in evaluating problem situations through the use of instrumental logic. As such, the social value theory of neoinstitutionalist thought represents the explicit and full recognition of the normative aspects of inquiry:

What neoinstitutionalists wish to raise to full scholarly awareness is that value premises permeate the whole of social inquiry. If inquiry is purposive-and it must be-it is value laden. Inquiry necessarily requires a continuing and successive exercise in the making of choices. To choose among or between items compels recourse to a criterion on the basis of which such choices can be made. ${ }^{26}$

The social value principle of neoinstitutionalist thought, drawing on contributions of Veblen, Ayres, and Foster and synthesized by Tool, proposes a criterion for social value that provides for "the continuity of human life and the noninvidious recreation of community through 
the instrumental use of knowledge" and stresses four fundamental elements: the principle of continuity, instrumental effectiveness, recreating community, and noninvidiousness. ${ }^{27}$ While some will argue that the application of the principle of instrumental value theory to problem situations does not lead to clear and obvious answers or resolutions, the process of instrumental value theory represents an explicit attempt to formulate not only a meaningful approach to inquiry, but an explicit criterion by which to evaluate problem situations facing society.

Finally, like the growth of knowledge tradition, neoinstitutionalists do not reject empirical analysis as such, but recognize the normative aspects of empirical research. What neoinstitutional thought provides, however, is an explicit value theory to guide empirical analysis, for " $[t]$ heory building and empiricism uninformed by explicitly articulated value premises are like loaded guns; we know they are very powerful but we know not where to aim them." 28

\section{Conclusion}

What is perhaps most important for the construction of a policy science is the ability of its practitioners to address existential problems of concern to the public. Neoclassical economics fails in this regard and much of the blame must be laid at the methodological doorstep. In its attempt to emulate a defunct positivist methodology in the hope of appearing "scientific," economics has become a sterile game played for the entertainment of economists.

One cannot help but question why neoclassical economics continues to invoke positivism as the only acceptable methodology when positivism has been in decline for more than twenty years within the philosophy of science. The answer, we believe, is that the positivist tradition has been instrumental in allowing orthodox economists to castigate those alternative research programs that do not support the ideological conclusions of neoclassicism. Thus, institutional economics has been dismissed under the rubric of "science" because it does not conform in toto to the rigorous demands of logical empiricism.

Our objective has been to argue that neoinstitutional thought can no longer be rejected by appealing to the authority of philosophy of science because recent developments within the philosophy of science have discredited the foundations of the positivist tradition and have much in common with the epistemological foundations of neoinstitutional thought.

The importance of understanding the post-positivist aspects of neoinstitutional thought can hardly be overstated in that the status of neo- 
institutional thought as a valid research tradition depends in large part on the recognition of the valid methodological aspects of this approach. We would agree with Paul Diesing, "[t]he one remaining useful route for the neoclassicists is to recognize the very limited validity of their perspective, and to treat it as a supplement to other, broader perspectives." ${ }^{29}$ Such a perspective we find in neoinstitutionalism.

\section{Notes}

1. Paul K. Feyerabend, "On the Critique of Scientific Reason," in Essays in Memory of Imre Lakatos, ed. R. S. Cohen, et al. (Dordrecht, Holland: D. Reidel, 1976) p. 137.

2. See Thomas Kuhn, The Structure of Scientific Revolutions, 2d ed. (Chicago: University of Chicago Press, 1970), and Paul K. Feyerabend, Problems of Empiricism, Vol. 2 (Cambridge: Cambridge Univirsity Press, 1981).

3. Bruce Caldwell, Beyond Positivism: Economic Methodology in the Twentieth Century (London: George Allen and Unwin, 1982), p. 23.

4. Paul A. Samuelson, "A Note on the Pure Theory of Consumer's Behaviour," Economica 5 (February 1938): 61-71 and "Consumption Theory in Terms of Revealed Preference," Economica 15 (November 1948): 243-53.

5. Stanley Wong, The Foundations of Paul Samuelson's Revealed Preference Theory: A Study by the Method of Rational Reconstruction (London: Routledge and Kegan Paul, 1978), p. 112-21.

6. Mark Blaug, "Kuhn versus Lakatos or Paradigms versus Research Programmes in the History of Economics," in Method and Appraisal in Economics, ed. Spiro J. Latsis (Cambridge: Cambridge University Press, 1976), pp. 173-74.

7. Caldwell, Beyond Positivism, p. 68.

8. Feyerabend, "On the Critique of Scientific Reason," 1981, p. 21.

9. Ibid., p. 24.

10. Caldwell, Beyond Positivism, p. 68.

11. Paul K. Feyerabend, Science in a Free Society (London: NLB, 1978), Section One.

12. Ibid., p. 33.

13. James K. Feibelman, Scientific Method (The Hague: Martinus Nijhoff, 1972), p. 50.

14. Paul K. Feyerabend, Against Method (London: NLB, 1975), p. 19.

15. Norwood R. Hanson, Patterns of Discovery (Cambridge: Cambridge University Press, 1958), p. 12.

16. Kuhn, The Structure of Scientific Revolutions, p. 198.

17. Frederick Suppe, ed., The Structure of Scientific Theories, 2d. ed. (Urbana, Ill.: University of Illinois Press, 1977), p. 632.

18. Marc Tool, Essays in Social Value Theory: A Neoinstitutionalist Contribution (New York: M.E. Sharpe, 1986).

19. John Dewey, The Quest for Certainty (New York: G. P. Putnam's Sons, 1929; reprinted by Perigee, 1982), p. 123.

20. John Dewey, Logic: the Theory of Inquiry (New York: Henry Holt and Co., 1938), p. 108. 
21. Ibid., p. 110.

22. Joseph Ratner, ed., Intelligence in the Modern World: John Dewey's Philosophy (New York: The Modern Library, 1939), p. 114.

23. H. S. Thayer, Meaning and Action: A Critical History of Pragmatism (New York: The Bobbs-Merrill Company, Inc., 1968), p. 168.

24. John Dewey, Theory of Valuation (Chicago: University of Chicago Press, 1939), p. 3.

25. Dewey, Logic: The Theory of Inquiry, p. 107.

26. Tool, Essays in Social Value Theory, p. 57.

27. Ibid., p. 56.

28. Steven R. Hickerson, "Instrumental Valuation: The Normative Compass of Institutional Economics," Journal of Economic Issues 21 (September 1987): 1117-43, at p. 1118.

29. Paul Diesing, Science and Ideology in the Policy Sciences (New York: Aldine Publishing Co., 1982), p. 416. 